Peter Berens

Trotzkisten gegen Hitler Köln: Neuer ISP-Verlag, 2007. 223 pp.

\title{
Daniel Gaido*
}

Este libro, un trabajo serio y bien documentado que será publicado a la brevedad en una versión inglesa por la editorial Verso, se basa en investigaciones en archivos y tiene su origen en una tesis de maestría presentada en 2005 en la Universidad de Duisburg-Essen. Trata ante todo de la historia de la Oposición de Izquierda dentro del Partido Comunista de Alemania, que llegó a tener unos 1.000 miembros y abogaba por la creación de una Frente Único Obrero contra el Nacional-Socialismo, contra la línea estalinista durante el "tercer período" ultra-izquierdista, cuando los socialdemócratas fueron denunciados como "socialfascistas" y los militantes comunistas debían crear "sindicatos rojos" paralelos. A continuación, después de la toma del poder por Hitler en enero de 1933, el libro describe la historia del grupo Internationalen Kommunisten Deutschlands (IS), la organización trotskista alemana, tanto dentro de Alemania (hasta su supresión por la Gestapo a finales de 1935, tras lo cual siguieron organizando células incluso en los campos de concentración nazis) como en el exilio, donde sus líderes editaban la revista Unser Wort. El autor se centra en el oeste de Alemania, específicamente en la región del Rin y el Ruhr.

Es difícil para un marxista a comienzos del siglo XXI, luego de la devastación de las organizaciones de izquierda por el fascismo y el estalinismo, hacerse una idea cabal del tamaño de las organizaciones marxistas en Alemania en los años 20 y hasta 1933. Berens proporciona algunos datos esclarecedores al respecto: "Así que había temporalmente una organización de izquierda y al menos cinco rudimentos de fracción dentro y fuera del KPD. Cada una de estas seis organizaciones contaba en sus orígenes con varios miles de miembros. La policía estimaba a comienzos de 1927 la membresía del Spartakusbund II en 6.000 personas, la de la Entschiedenen Linken (Izquierda Decidida) en 4.000, la del grupo Kommunistische Politik en 3.000, la de la Oposición de Wedding (un suburbio de Berlín) en 3.000, la de la fracción Fischer-Maslow en 6.000-7.000 y la de la fracción de Hugo Urbahns en 5.000 personas" (p. 21). Los grupos de oposición de izquierda contaban por ende con aproximadamente unos 20.000 miembros, sobre una membresía total del Partido

\footnotetext{
* Consejo Nacional de Investigaciones Científicas y Técnicas (CONICET), Argentina, danielgaid@ gmail.com
} 
Comunista alemán de 112.000 a 144.000 personas entre 1925 y 1928 (p. 22). Esto, a su vez, era un gran retroceso comparado con la época en que el KPD era dirigido por Paul Levi, antes del putsch conocido como la Acción de Marzo de 1921 (organizada por el enviado de Zinoviev, Béla Kun), cuando llegó a tener 350.000 miembros.

Berens muestra que los trotskistas alemanes tomaron parte activa en la resistencia al régimen nazi. Informa, por ejemplo, sobre la batalla de Büchen, una localidad en Schleswig-Holstein. Dicha batalla fue "uno de los pocos ejemplos de resistencia armada a la toma del poder" por los Nazis (p. 59). El 5 de marzo de 1933, el domingo en el cual se llevaron a cabo las elecciones parlamentarias luego del incendio del Reichstag, las SA y las SS intentaron realizar una marcha a través del barrio obrero de Remscheid en Büchen, un bastión del IKD. Fueron recibidos con una lluvia de disparos desde las casas vecinas y desde un terraplén. Sólo la policía pudo romper la resistencia, con la ayuda de vehículos blindados. Esta lucha no había sido tratada en ninguna investigación previa.

Luego de la toma del poder por los nazis en enero de 1933, el grupo IKD, cuyos efectivos se redujeron a unos 300 miembros, pasó a la clandestinidad junto con el resto de los partidos de izquierda, y comenzó a organizarse en células de 5 miembros. Fueron capaces de resistir la persecución de la Gestapo por dos años, antes de caer en una redada, organizada a nivel nacional, en noviembre de 1935. Aun así, algunas de las células (por ejemplo, en Leipzig) continuaron operando, y los compañeros detenidos, que fueron torturados por la Gestapo, organizaron células trotskistas en las prisiones y campos de concentración nazis. En Buchenwald, por ejemplo, los detenidos trotskistas formaron una célula de la "Internationalen Kommunistischen Liga" (IKL), el nombre que adoptó la Oposición de Izquierda internacional luego de llegar a la conclusión de que la Internacional Comunista no podía ser reformada, debido a la falta de reacción de los partidos comunistas ante las consecuencias de la desastrosa política implementada por el estalinismo en Alemania. Los prisioneros trotskistas se reunían con regularidad en el campo de concentración de Buchenwald y discutían temas políticos.

En la libertad eran a menudo las mujeres trotskistas (a quien Berens dedica uno de los capítulos del libro) las que mantenían en pie la resistencia y trataban de no dejar que las conexiones con el exilio se extinguieran. Sin embargo, una progresiva desmoralización se apoderó del liderazgo del grupo IKD en el exilio, dirigido por Josef Weber, el cual terminaría emigrando a los Estados Unidos. Con el inicio de la Segunda Guerra Mundial, las estructuras de la organización trotskista, que de alguna manera se habían mantenido en pie hasta entonces, mostraron signos significativos de desintegración. Muchos miembros del IKD huyeron del país o fueron reclutados a batallones de castigo o unidades del ejército. Una proporción significativa de ellos murió en la guerra. Sus destinos se detallan 
en el apéndice biográfico, que rescata la vida y la obra de estos luchadores comunistas contra el estalinismo y el nazismo. Del grupo de los trotskistas alemanes salió uno de los colaboradores más estrechos de Trotsky, Heinz Epe ("Walter Held"), asesinado por los estalinistas el 28 de octubre de 1942.

Berens en parte polemiza y en pase se basa en los trabajos existentes sobre la historia del trotskismo en Alemania, sobre todo Wolfgang Alles, Zur Politik und Geschichte der deutschen Trotzkisten ab 1930 (Köln: Neuer ISP-Verlag, 2. Auflage, 1994) y Stefan Goch, "Westdeutsche Trotzkisten im Widerstand gegen den Nationalsozialismus und im Exil," Internationale wissenschaftiche Korrespondenz zur Geschichte der deutschen Arbeiterbewegung, Vol. 32, 1996, S. 143-171. Lamentablemente este material no ha sido traducido al castellano, ni a ninguna otra lengua.

El autor comete algunos errores al atribuir a Paul Levi un "comunismo de derecha" inexistente, lo cual es una repetición inconsciente de las calumnias zinovievistas contra Levi (p. 14). Un segundo problema se presenta en las páginas 100-101, en las que básicamente Berens sostiene que el grupo IKD fue suprimido debido a su estructura centralista democrática - a pesar de que él mismo señala anteriormente que el SAP, que tenía una estructura descentralizada, fue suprimida por la Gestapo incluso antes.

El mayor problema, sin embargo, se presenta en la sección 6. Neubeginn nach 1945, la cual presenta a Georg Jungclass como el continuador de la tradición trotskista en Alemania después de la Segunda Guerra Mundial. Aunque el libro Berens es un estudio académico que busca establecer la verdad objetiva, el autor no oculta su pertenencia al Secretariado Unificado de la IV Internacional, y este es un lugar donde su filiación política nubla su juicio. Berens debería al menos haber mencionado que el principal historiador del comunismo alemán, Hermann Weber, criticó la adaptación de Jungclass al estalinismo: "En mi juventud yo era un funcionario de la organización juvenil del Partido Comunista en Alemania Occidental, por lo que aterricé en prisión por 6 meses. Yo había entrado en conflicto con la dirección del partido como crítico del estalinismo ya antes de mi encarcelamiento y después, en 1954, fui expulsado del partido junto con mi esposa Gerda. Durante esos años me concentré en buscar organizaciones políticas que defendieran el socialismo y lucharan contra el estalinismo desde ese punto de vista. A principios de la década de 1950, los entonces principales miembros de la organización trotskista en Alemania, como Georg Jungclas, tuvieron muchas conversaciones conmigo, pero al final no me pudieron convencer políticamente. Cuando habían estado activo dentro de la UAP [Unabhängige Arbeiter-Partei] en 1951, habían pintado una imagen demasiado optimista de titismo, que yo consideraba una nueva variante del estalinismo." ("Robert Service has 
written a diatribe, not a scientific polemic!'. A conversation with Professor Hermann Weber. 28 November 2011)

Pero estas críticas sobre cuestiones que no hacen al tema central del libro no deben inducirnos al error: el libro de Berens es una adición importante a la bibliografía existente sobre la historia del trotskismo y debería ser leído por todos aquellos interesados en la historia del socialismo, así como por los militantes socialistas interesados en conocer las lecciones de las luchas de sus antecesores. 